\title{
COMMONLY USED CHEMICALS IN SHRIMP GHERS AT SHYAMNAGAR UPAZILA IN SATKHIRA, BANGLADESH
}

\section{Mohammad Masud Kamal, Md. Rafiqul Islam Akhand ${ }^{1 *}$ and Binay Kumar Roy ${ }^{2}$}

Innovision Consulting Private Ltd., Khulna Division, Khulna; ${ }^{1}$ Innovision Consulting Private Limited, Niketan, Gulshan-01, Dhaka; 'Upazila Fisheries Office, Department of Fisheries, Dashmina, Patuakhali, Bangladesh

*Corresponding author: Md. Rafiqul Islam Akhand, E-mail: rafiqul.akhand@innovision-bd.com

\begin{tabular}{|c|c|}
\hline ARTICLE INFO & ABSTRACT \\
\hline Received & The study was carried out to know the purpose of the use of chemicals and current status of \\
\hline 20.08. & $\begin{array}{l}\text { chemicals used in various aquaculture activities in Shyamnagar upazila between August } 2007 \\
\text { and February 2008. A total of } 50 \text { shrimp farmers and chemical sellers were selected for } \\
\text { questionnaire interview. Data were collected through PRA tools like questionnaire interview, }\end{array}$ \\
\hline Accepted & Focus Group Discussion and key informant interview. All interviewed farmers were male with \\
\hline 31.08 .2015 & $\begin{array}{l}\text { an average age of } 36-45 \text { years and their average family size was } 7 \text { members. Commonly used } \\
\text { chemicals found in the study area were lime, urea, Triple super phosphate (TSP), Potassium } \\
\text { permanganate, Vitamins, Antibiotics, (mainly oxytetracycline and chlorotetreacycline), } \\
\text { rotenone, phosphate, phostoxin, sumithion, melathion, timsen, bioaqua, oxymax/oxyflow, }\end{array}$ \\
\hline 04.09 & $\begin{array}{l}\text { aquanarish, aqua clean and théoden. Health management and disease treatment were the } \\
\text { major activities where farmers were seen to use a lot of chemicals. Study identified some } \\
\text { diseases and conditions like white spot disease, yellow head disease, heavy qill and surface }\end{array}$ \\
\hline Key words & disease, brown spot disease, nutritional disease and environmental disease. This study \\
\hline Chemi & demonstrated that most of the farmers used chemicals and antibiotics indiscriminately without \\
\hline Shrimp farming & knowing their mode of action, doses and appropriate procedure of application. Study also \\
\hline Impact & $\begin{array}{l}\text { to shrimp viral disease. The study also highlighted the names and approximate price of } \\
\text { aculture chemicals available with the chemical sellers in the study areas. }\end{array}$ \\
\hline
\end{tabular}

To cite this article: MM Kamal, MRI Akhand and BK Roy, 2015. Commonly used chemicals in shrimp ghers at Shyamnagar Upazila in Satkhira, Bangladesh. Res. Agric. Livest. Fish. 2 (2): 343-351.

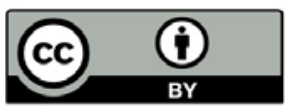

This is an open access article licensed under the terms of the Creative Commons Attribution 4.0 International License

www.agroaid-bd.org/ralf, E-mail: editor.ralf@gmail.com 


\section{INTRODUCTION}

Bangladesh is a small country lying in the sub tropic belt is blessed with a large coast line of about $710 \mathrm{~km}$ and (Pramanik, 1988). The coastal area is densely populated depending mainly on agriculture, fisheries and forestry. It is estimated that out of the 3.6 million hectare coastal areas about 2.5 million ha brackish water areas are suitable for shrimp culture, of which about 0.25 million ha have been projected as very good area for coastal aquaculture. The rapid expansion of shrimp culture in the past few years is one of the most remarkable developments in the fisheries sub-sector. It is noted that shrimp production through culture has grown from less than $1000 \mathrm{mt} / \mathrm{yr}$ to over17000 mt/yr in 1986. With the improved management and culture techniques the production has been increased to $37000 \mathrm{mt}$ from an area of 115,000 ha in 1991-92 (Giasuddin, 1993). Shrimp farming plays a significant role in the economy of Bangladesh. Processed shrimp comprises the second largest export commodity of this country. Shrimp is second to garments in respect of foreign exchange earnings. Bangladesh earned Tk. 3702 crore from frozen fish and shrimp export in $2006-2007$ fiscal year. About 90,000 persons are involved in shrimp farming (Hossain 1994) in Bangladesh.

Most systemic antibacterial employed in aquaculture generally fall within following categories (Alderman and Michel, 1992) - Tetracycline (oxytetracycline, chlorotetracycline and doxycycline), Marcolide antibiotics erythromycin, B- lactam antibiotics (amoxicillin, penicillin), Aminoglycoside (streptomycine, neomycin, kanamycin), Chloramphenicol, Sulphanomides, Quinolones (oxolinic acid) and Nitrofuran (Weston, 1996). The use of chemicals in aquaculture systems for various purposes is widely recognized. They are essential components in pond construction, health management, enhancements of natural aquatic productivity, transportation of live organisms, feed formulation, manipulation and enhancement of reproduction, growth promotion and processing and value enhancement of the final product (Subasingheet al 1996; GESANP, 1997). The benefits of chemicals usages in aquaculture are many. They can be classified by the purpose of use, the type of organisms under culture, the life cycle stage for which they are used, the culture system are intensity of culture, and by the type of people who use them.

The Food and Drug Administration (FDA) is charged with protecting the public from exposure to undesirable and dangerous compounds therefore any compound that is given to shrimp or applied to the water must first undergo careful scrutiny and testing to make certain that it: (1) does what it is supposed to do in terms of being effective in treating an effective disease, (2) does no harm to the shrimp, and (3) is not stored in the flesh and passed on to the person that eats the shrimp. Extensive and expensive studies are required to make these determinations. Only after these questions are satisfied is a specific compound "licensed" for application. There is no government body that regulates the distribution and the trade of shrimp drugs in our country, Government can not issue license for selling shrimp chemotherapeutics. However, regulation has been possible through the Ministry of Fisheries and Livestock. With rapid intensification, serious shrimp disease problems have surfaced. Shrimp farmers have been quick to realize the seriousness of shrimp health problems and the importance of shrimp health management. Shrimp farmers now feel the need of familiarize themselves with simple diagnostics and therapeutic techniques.

\section{MATERIALS AND METHODS}

\section{Selection of the study area and sample size}

Most of the shrimp ghare are situated in south-western part of Bangladesh. Satkhira is the most important and promising area for shrimp (galda and bagda) farming because of availability of wild post-larvae in costal belt. A total of 50 shrimp farmers and chemical sellers were selected for questionnaire interviews in selected areas.

\section{Participatory rural appraisal (PRA)}

PRA is a group of method to collect information from target grouping a participatory fashion (Chambers, 1992). The advantage of PRA over other methods is that through wide participation of the community, the information collected is likely to be more accurate. The participation of retailers provides an opportunity for cross checking individual option as well as allowing the community to discuss the issues that they fell important, rather than responding to a questionnaire. For the present study, PRA tool such as one to one questionnaire interview, focus group discussion (FGD), cross check interview etc. were conducted with retailers. 


\section{Data collection methods}

The data collection as well as field survey was under taken for six months from August 2007 to February 2008 in selected areas. Data were collected by direct one to one interview with Shrimp farmers and chemical seller who were selected randomly; time required for each interview was about 1-1.5 hours, and crosscheck interview with key informants to verify the information from questionnaire interviews with different NGOs who were working in that resign and Thana Fisheries Officers (TFO). Also Focus group discussions (FGD is a discussion meeting with a selected group of retailers to follow a set of detailed guidelines designed to generate information on a particular set of topic) were held with the group of shrimp farmers (each group size was 6-12 retailers) to collect accurate information. Theis and Graty (1991) noted that small group is most suitable for FGD.

\section{Processing and Analysis of data}

After collection, the data were edited carefully to eliminate possible errors and inconsistencies. Then it was transferred to a computer (MS Excel) after careful examination and checking of the information. The processed data were finally analyzed to produce grapes by using Microsoft Excel.

\section{RESULTS}

\section{Use of chemicals during gher preparation and culture period}

Different types of chemicals were found to use by the farmers during their various aquaculture activities but they did not use shrimp poison. During gher preparation farmers used lime, Urea and TSP at different combination. Urea and TSP were found to use as a fertilizer in the gher. During nursery gher preparation, most of the farmers (58 \%) used a combination of lime, Urea and TSP at 30 days interval (Table 1). Similar conditions were seen to gher preparation; about $36 \%$ farmers used fertilizers of a combination of lime, urea and TSP. However, during culture period most of the farmers (54\%) used only lime.

Table 1. Chemicals used in gher preparation and culture period

\begin{tabular}{lcc}
\hline Chemicals & Farmers $\mathbf{( n = 5 0 )}$ & \\
\hline & Gher preparation & During culture \\
\hline Lime & $6(12)$ & $27(54)$ \\
Lime and Urea & $15(30)$ & $5(10)$ \\
Lime, Urea and TSP & $29(58)$ & $18(36)$ \\
\hline
\end{tabular}

\section{Doses of different chemicals during gher preparation and culture}

It was observed that about $80 \%$ farmers were applied lime during gher preparation at $<0.3 \mathrm{~kg} / \mathrm{decimal}$ while $84 \%$ farmers followed the same during culture period (Table 2). Urea is one of the most important chemical fertilizers during both in gher preparation and culture period. Actually most of the shrimp farmers did not use the urea during gher preparation and the culture period, Only $20 \%$ farmers used urea at $<50 \mathrm{~g} / \mathrm{decimal}$ during gher preparation and $10 \%$ farmers used urea during culture period at $<50 \mathrm{~g} / \mathrm{decimal}$. In gher preparation, only $10 \%$ farmers used TSP at $<20 \mathrm{~g} /$ decimal while during culture period only $6 \%$ farmers used this dose (Table 2). It was also found that most of the shrimp farmers did not use any TSP in their gher. About $70 \%$ farmers did not used rotenone, only 20 farmers were applied rotenone at $15-20 \mathrm{~g} / \mathrm{dec}$. Phostoxin has been found in the market as tablet form. Each tablet weights about 3gm. Only 4\% used phostoxin at 2-4 g/dec during gher preparation. Although thiodrin has been banned by the government $10 \%$ shrimp farmers used thiodrin to remove unwanted fish, crab, snakes and insects which came from India illegally.

\section{Use of insecticide/pesticide and vitamin during shrimp health management practices}

Insecticides were used as chemical mainly for health management, to kill argulus, copepod etc. which are harmful to both fingerlings and white fish. Sumithion, melathion and dipterax found available as insecticide in the market. . Most of the shrimp farmers (94\%) did not use sumithion and melathion, The few farmers were found to use sumithion and melathion and it was applied before releasing of $\mathrm{PL}$ at the gher. 
Insecticides were mainly used in nursery gher with white fish. Some farmers also used it in grow out gher. Most of the farmers used sumithion at 1.5-2.0 ml/decimal while the reported dose of melathion was 2.3-3 $\mathrm{ml} /$ decimal. Majority of the farmers (90\%) did not use vitamin, only $10 \%$ farmers used vitamin premix with feed for better growth and energy of shrimp. The average dose of vitamin premix was $1 \mathrm{gm} / \mathrm{kg}$ feed.

Table 2. Doses of Lime, Urea, TSP, Rotanon, Phostoxin, Thiodrin etc.

\begin{tabular}{|c|c|c|c|}
\hline \multirow{2}{*}{ Chemicals } & \multirow[b]{2}{*}{ Dose } & \multicolumn{2}{|c|}{ Farmers(n=50) } \\
\hline & & Gher preparation & During culture \\
\hline \multirow{4}{*}{ Lime } & $0.3 \mathrm{~kg} / \mathrm{dec}$ & $40(80)$ & $42(84)$ \\
\hline & $0.3-1 \mathrm{~kg} / \mathrm{dec}$ & $6(12)$ & $4(8)$ \\
\hline & $1-1.5 \mathrm{~kg} / \mathrm{dec}$ & $2(4)$ & $2(4)$ \\
\hline & $>1.5 \mathrm{~kg} / \mathrm{dec}$ & $2(4)$ & $2(4)$ \\
\hline \multirow{5}{*}{ Urea } & No use & $30(60)$ & $40(80)$ \\
\hline & $<50 \mathrm{~g} / \mathrm{dec}$ & $10(20)$ & $5(10)$ \\
\hline & $50-100$ g/dec & $5(10)$ & $2(4)$ \\
\hline & $100-150 \mathrm{~g} / \mathrm{dec}$ & $3(6)$ & $2(4)$ \\
\hline & $>150$ g/dec & $2(4)$ & $1(2)$ \\
\hline \multirow{4}{*}{ TSP } & No use & $40(80)$ & $44(88)$ \\
\hline & $<20 \mathrm{~g} / \mathrm{dec}$ & $5(10)$ & $3(6)$ \\
\hline & $20-50 \mathrm{~g} / \mathrm{dec}$ & $4(8)$ & $3(6)$ \\
\hline & $>50 \mathrm{~g} / \mathrm{dec}$ & $1(2)$ & $0(0)$ \\
\hline \multirow{5}{*}{ Rotenone } & No use & $35(70)$ & - \\
\hline & $15-20 \mathrm{~g} / \mathrm{dec}$ & $10(20)$ & - \\
\hline & $20-30 \mathrm{~g} / \mathrm{dec}$ & $2(4)$ & - \\
\hline & $30-40 \mathrm{~g} / \mathrm{dec}$ & $1(2)$ & - \\
\hline & $40-50 \mathrm{~g} / \mathrm{dec}$ & $2(4)$ & - \\
\hline \multirow{5}{*}{ Phostoxin } & No use & $40(80)$ & - \\
\hline & $2-4 \mathrm{~g} / \mathrm{dec}$ & $2(4)$ & - \\
\hline & $4-6 \mathrm{~g} / \mathrm{dec}$ & $1(2)$ & - \\
\hline & $6-8 \mathrm{~g} / \mathrm{dec}$ & $1(2)$ & - \\
\hline & $8-10 \mathrm{~g} / \mathrm{dec}$ & $1(2)$ & - \\
\hline \multirow{2}{*}{ Thiodrin } & No use & $47(94)$ & - \\
\hline & $2-4 \mathrm{~g} / \mathrm{dec}$ & $3(6)$ & \\
\hline
\end{tabular}

\section{Shrimp disease problem and use of chemicals in disease treatment}

Farmers were applied a variety of chemicals for the treatment of their diseased shrimp. Therefore, emphasis was given to find out, different types of shrimp disease incidence in different culture systems and the way by which the farmers encountered those disease using chemicals and drugs. It was observed that in surveyed areas different types of shrimp disease like white spot disease, Yellow head disease, Heavy gill and surface fouling disease, nutritional disease, brown spot disease, filamentous disease, environmental disease, and some unknown disease were occurred in different times. 

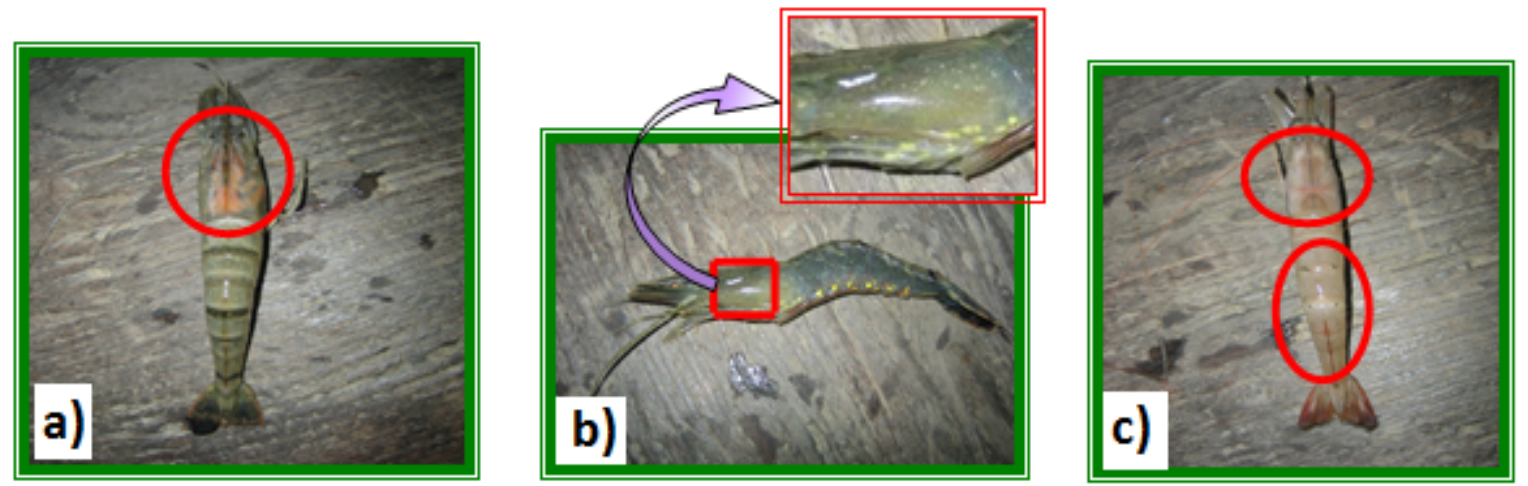

Figure 1. Plate a) Yellow head disease, b) White spot disease, c) Brown spot disease

Almost all the farmers attempt to treat their shrimp with various chemicals. Maximum farmers (60\%) used lime followed by $20 \%, 12 \%, 18 \%, 22 \%, 10 \%, 6 \%, 12 \%, 24 \%, 10 \%, 6 \%, 14 \%, 4 \%$, and $30 \%$ farmers used potash $\left(\mathrm{KMnO}_{4}\right)$, Copper sulfate $\left(\mathrm{CuSO}_{4}\right)$, Malachite green, Methylene blue, Timsen, water clear, Aquanarish, Bio aqua, Oxymax, Aqua-Z, Formaline and Aluminium oxide Antibiotic respectively with either individually or in various combinations.

For chemotherapy, the farmers did not use only one chemical for particular diseases but they used combination of drugs as general treatment of almost all kind of disease with few exception. Farmers were seen to use lime against white spot diseases, yellow head disease etc. at average dose of 300-500 g/dec.

Potassium permanganate was used by the farmers for white spot disease, yellow head disease, and black gill disease and for all other diseases. Oxytetracycline and clorotetracyclin were the most commonly used as antibiotics for bacterial disease such as vibriosis. They also used timsen for black gill disease, brown spot disease. Bioaqua used for reducing ammonia. Farmer used vitamin with feed for nutritional disease. Formaline, methylin blue and malachite green are used for all disease of shrimp. Aquanarish, water clear,zeolite use for clearing of water and for pathogen free. When shrimp float and become near the dike fermer use oxymax (80 \% calcium carbonate) or oxy flow for removing oxygen deficiency (Table 3).

Farmers were found to use chemicals from their own experience, suggestion from other farmers or from chemical sellers. They were not confident about the dose and application of those chemicals. They also gave different opinion about the effectiveness of the treatment.

Table 3. Chemicals used by farmers in disease treatment

\begin{tabular}{|c|c|c|c|c|c|}
\hline \multirow[t]{2}{*}{ Chemicals } & \multicolumn{2}{|c|}{ Farmers } & \multirow{2}{*}{$\begin{array}{l}\text { Doses } \\
\text { g/dec }\end{array}$} & \multirow{2}{*}{ Frequency } & \multirow{2}{*}{$\begin{array}{c}\text { Method } \\
\text { of application }\end{array}$} \\
\hline & $\mathrm{n}=50$ & $\%$ & & & \\
\hline Lime & 30 & 60 & $200-300$ & $1-2$ & Mixed with water and spray \\
\hline Potash $\left(\mathrm{KMnO}_{4}\right)$ & 10 & 20 & $8-1$ & $1-2$ & Mixed with water and spray \\
\hline Copper sulfate & 12 & 24 & $7-10$ & $1-2$ & Mixed with water and spray \\
\hline Malachite green & 9 & 18 & $5-8$ & $1-2$ & Mixed with water and spray \\
\hline Methylene Blue & 11 & 22 & $6-7$ & $1-2$ & Mixed with water and spray \\
\hline Timsen & 5 & 10 & $2.5-3.5$ & $1-2$ & Mixed with water and spray \\
\hline Water clear & 3 & 6 & $2-6$ & $1-2$ & Mixed with water and spray \\
\hline Aquanarish & 6 & 12 & $3-5$ & $1-2$ & Mixed with water and spray \\
\hline Bio aqua & 12 & 24 & $2-3$ & $1-3$ & Mixed with water and spray \\
\hline Oxymax/oxy flow & 5 & 10 & $2-5$ & $1-2$ & Mixed with water and spray \\
\hline Aqua clean & 3 & 6 & $2-4$ & $1-2$ & Mixed with water and spray \\
\hline Formalin & 7 & 14 & $4-6$ & $1-2$ & Mixed with water and spray \\
\hline Aluminium oxide & 4 & 8 & $3-6$ & $2-3$ & Mixed with water and spray \\
\hline Oxytetracycline/ & 15 & 30 & $1-2$ & $3-5$ & With feed \\
\hline Vitamin & 5 & 10 & $1-2$ & $2-3$ & With feed \\
\hline
\end{tabular}




\section{Side effect of chemicals on user}

About $44 \%$ farmers knew about particular chemicals from chemical seller while only $20 \%$ farmers knew it from Upazila Fisheries Officer (UFO). Every antibiotics or chemicals has side effect either good or bad. It was reported that most of the shrimp farmers (95\%) reported that they did not find any side effects on shrimp due to use of chemicals

\section{Chemical seller and available chemicals with them}

Around half of the sellers (52\%) reported that they were doing this business last 3-5 and about $32 \%$ sellers said that farmers seek suggestion from them when they buy particular chemical. When ask about expire date of chemicals, all the chemical sellers reported that they well aware about the date of expire of chemicals. The name of aquaculture chemicals and their average price which were found in the shops of chemicals seller are given in (table- 4), some chemicals which were available to the seller but not found to use by the farmers included fish calipus, aqua boost, escofnil etc.

Table 4. List of chemicals available with chemical seller

\begin{tabular}{|c|c|c|}
\hline Name of chemicals & Trade name & Price (Tk) \\
\hline Calcium carbonate & Lime & $12 / \mathrm{kg}$ \\
\hline Urea & No trade name & $6-7 / \mathrm{kg}$ \\
\hline TSP & No trade name & $50 / \mathrm{kg}$ \\
\hline Cow dung & No trade name & $2-4 / \mathrm{kg}$ \\
\hline Potash & No trade name & $18 / \mathrm{kg}$ \\
\hline $\mathrm{CuSO}_{4}$ & No trade name & $360 / \mathrm{kg}$ \\
\hline $\mathrm{ZinSO}_{4}$ & No trade name & $45 / \mathrm{kg}$ \\
\hline $\mathrm{Al}_{2} \mathrm{O}_{3}$ & Zeolite & $40 / \mathrm{kg}$ \\
\hline $\mathrm{N}$-alkyl diethyl benzyl ammonium chloride & Timsen & $238 / 50 \mathrm{~g}$ \\
\hline Saponin and glyco component & Bio aqua & $300 / 100 \mathrm{ml}$ \\
\hline Calcium peroxide $80 \%$ & Oxy max/oxy flow/oxy marine & $330 / 500 \mathrm{~g}$ \\
\hline B glucan and mannos polymer & Fibosel & $335 / 200 \mathrm{~g}$ \\
\hline Free amino acid and nitrogen compound & Aquasavor & $350 / 500 \mathrm{~g}$ \\
\hline Non-ionic stimulant & Predator & $50 / \mathrm{kg}$ \\
\hline Do not know & Rotenone (9\%) & $300 / \mathrm{kg}$ \\
\hline Do not now & Aqualime & $200 / \mathrm{kg}$ \\
\hline Do not know & Aquanarish & $230 / \mathrm{kg}$ \\
\hline Methylene blue & - & $280 / 250 \mathrm{~g}$ \\
\hline Malachite green & - & $300 / 250 \mathrm{~g}$ \\
\hline Do not know & Thiodrin & $320 / \mathrm{kg}$ \\
\hline Vitamin $B+C$ & No trade name & $50 / 100 \mathrm{~g}$ \\
\hline Vitamin B & No trade name & $55-60 / 100 g$ \\
\hline Vitamin C & No trade name & $50-60 / 100 \mathrm{~g}$ \\
\hline Vitamin premix & Aqua boost /Eon fish grower & $230 / \mathrm{kg}$ \\
\hline Oxytetracyclin & Renamycine /Tetravet / O tetra (20\%) & $75 / 100 \mathrm{~g}$ \\
\hline Chlorotetracyclin & Chlorosteclin(15\%) & $350 / \mathrm{kg}$ \\
\hline Sulphamethoxazole and trimethoprim & Cotrim vet & $70 / 20 t a b$ \\
\hline Salfatrin & Polytrim DS & 3/tab \\
\hline Fenitrothion & Sumithion & $60 / 100 \mathrm{ml}$ \\
\hline Aqua $Z$ \& Aqua 7 & - & $80 / \mathrm{Kg}$ \\
\hline
\end{tabular}




\section{DISCUSSION}

There were found that shrimp farmers of different categories used various types of chemicals. Commonly used chemicals found in the present study were aqua-7, aqua clean, limes, urea, TSP, potassium permanganate, various disinfectant, various antibiotics, rotenone, oxymax, bioaqua, thidrin, sumithion, melathion etc. Very few previous studies also revealed the similar reports about the use of chemicals in aquaculture of Bangladesh (Phillips, 1996; Brown and Brooks, 2002; DoF, 2002).

There are many purpose of use of chemicals in aquaculture such as Gher construction, water treatment, health management, enhancement of natural aquatic productivity, transportation of live organism, feed formulation, manipulation and enhancement of reproduction, growth promotion, processing and value enhancement of the final product (Subasinghe et, al., 1996). In the present study, it has been found that most of the farmers used chemicals for pond preparation, health management and disease treatment. However, shrimp disease treatment was major area where most of the chemical used Shrimp farmers suffered from high incidences of diseases than other white fishes. The major diseases and conditions reported by shrimp farmers were white spot disease, yellow head disease, black gill disease, nutritional disease, brown spot disease and other bacterial, viral and fungal diseases.

The use of chemical was also influenced by the culture system. In the most simple and extensive systems, this was limited to fertilizers, while in more complex semi intensive and intensive system a wide range of natural and synthetic compounds were used (Sultana, 2004). In the present study, it has been found that shrimp farmers used limited chemicals than other white fish farmers but shrimp farming industry is mostly commercial, and farmers invest a lot of money. It has also been found from the present study that farmer used some chemicals indiscriminately. On a worldwide basis, only a small number of chemicals are legally approved for use in aquaculture. The use of drugs and chemicals by the US aquaculture industry is strictly regulated by the US Food and Drug Administration (FDA) and the US Environmental Protection Agency (EPA). In the US, there are only six drugs approved for use in aquaculture: one anesthetic, one parasiticide, one spawning agent and three antibiotics. All drugs must be used according to label instructions. Oxytetracycline and a potentiated sulfonamide are antibiotics approved for use to treat disease but only in certain types of aquatic animal and only to treat certain diseases (Bendrook, 2002).

Farmers in the present study used common fertilizers like urea and TSP. They also used agricultural lime for various purposes. But many farmers were found to use those at a higher dose than the previous use. Excess use of urea and TSP may cause shrimp mortality due to ammonia toxicity and certain phytoplankton bloom which are responsible for oxygen depletion. On the other hand, some farmers did not know the proper way of application. Understanding the $\mathrm{p}^{\mathrm{H}}$ in the gher water is very important before application of lime. Majority of the farmers reported that they applied lime without measuring the $\mathrm{pH}$ of the water of their gher. Lime has some negative effects including direct toxic effect due to high $\mathrm{pH}$ on shrimp and phytoplankton. Application and precipitation of phosphate happens due to raised $\mathrm{pH}$ level immediately after application (BAFRU, 1995).

Chemotherapy is a wider area in aquaculture where many chemicals are used. Generally, disease treatment in aquaculture can be of great value when chemicals are used properly but when improperly applied they can cause large losses of shrimp. In order to use chemicals to the water or feed properly, it is important to accurately determine the dosage and the best application methods. Chemicals can react differently in water depending upon water quality, the target species and the life stages of the species. Larval stages and younger shrimp are usually more sensitive to chemicals. Therefore, it is important to follow the recommended dosages and methods of application of particular chemical. Also, to avoid complications following chemicals application, a simple bioassay can be conducted to determine the response to the treatment. Moreover, it is the legal responsibility of the person prescribing the treatment and the farmer to ensure illegal residues are not present in shrimp harvested for human consumption. However, none of the above measures were found to follow by the farmers while treating their shrimp with chemicals.

Bacterial disease of shrimp and fish can be successfully treated with antibiotics. However, to ensure the correct antibiotic, the causative agent of the disease needs to be identified via a sensitivity test at diagnostic laboratory. Antibiotics were seen to be used indiscriminately especially in the white fish farms without knowing the exact reasons of disease. Farmers do not have training about the use of chemicals during chemotherapy. It is widely recognized that excessive use of antibiotics contributes to the development of resistant strains of bacteria. In Bangladesh, $30 \mathrm{mt}$ of tetracycline and $10 \mathrm{mt}$ of choloramphenicol are imported per year for human 
consumption of which a small fraction are being used for shrimp and fish disease treatment (M. H. Khan, $\mathrm{BFRI}$ ) These antibiotics are readily available in every corner of our country. Prescription is not compulsory for purchasing antibiotics from the market.

In the present study, farmers were also seen not to be aware about the mode of action of particular chemical. As a consequence, during disease treatment first they try with one chemical and if it does not work, thy try for other one. They used doses of particular chemical on either from their own experiences, or from the instruction of the packet, if there is any and from the suggestion of chemical sellers.

There are three broad groups of people who deal directly with aquaculture chemicals: manufactures and traders, farmers and consumers. Manufacturers and traders should work towards manufacturing and supplying appropriate species and systems- specific chemicals; they should facilitate availability through ensuring an adequate supply of such chemicals; should provide accurate and adequate information to farmers. The private sector should also conduct more research and development towards reducing the harmful impacts of chemicals on aquaculture system, and should work to improve public awareness of chemical use. Farmers should work to understand the on farm management of chemical use in order to increase effectiveness and minimize adverse impacts. They should also inform themselves of the advantages and disadvantages of chemical use in each specific situation. Consumers should be aware of the health consequence of chemical misuse.

There are few alternatives to minimize the adverse effects of chemical such as simply use less of them. Other alternatives may be use of recirculation systems, bioremediation use of probiosis, immunostimulants, vaccination and alternative therapeutants. However, policy makers, researchers, and scientists should work together in addressing the issues of chemical use, with the view to reduce the adverse impacts. More research should be conducted and they should be focused on providing answers to the problems related to the use of chemicals. Efforts should be made towards finding non-chemotherapeutic solutions to health management and disease control.

\section{CONCLUSION AND RECOMMENDATION}

Health management and disease treatment were the major area of aquaculture. Since farmers used a lot of chemicals in disease management, an attempt was made to have farmer's perception about shrimp diseases in their systems. Some problems are of the use of chemicals by the farmers which include lack of knowledge of the chemicals, doses, methods of application and abuse of chemical. Therefore, in order to ensure effective use of chemicals in shrimp gher, it is recommended that the farmers should be trained about the basic purposes and the use of chemicals, appropriate doses, method of application, their safety and side effects. There is a badly need for better understanding of shrimp farm health management and disease prevention practice that could reduce the need for chemical treatments. Judicious use is essential to keep this tool effective.

\section{REFERENCES}

1. Alderman DJ. 1992. Malachite green and alternatives as therapeutic agents. European Aquacult. Soc. Spec. Publ., 16: 235-244.

2. BAFRU (Bangladesh Agriculture and Fisheries Research Unit), 1995. Technical Manual on Carp Culture. pp. 5-53.

3. Benbrook, C. M., 2002. Antibiotic drug use in U.S. aquaculture: Internet materials at URL http://www.iatp.org/.

4. Brown D and Brooks A. 2002. A survey of disease impact and awareness in pond aquaculture in Bangladesh, the Fisheries and Training Extension Project-Phase II. In: Primary Aquatic Animal Health Care in Rural, Small Scale and Aquaculture Development, Arther, J. R., M.J. Phillips, R.P. Subasinghe, M.B. Reantaso and I.H MacRae. (eds.) FAO Fish. Tech Pap. No. 406. pp. 85-93.

5. Chowdhury MBR, Islam MS and Uddin MN. 1986. Occurrence of ulcer disease in Pangasiussutchi in Bangladesh. In: The Fourth Indian Fisheries Forum. Asian Fisheries Society Indian Branch. 187p. 
6. DoF, 2002. Fish Fortnight Compendium. 10-24 August 2002, Department of Fisheries, MatshaBhaban, Dhaka. pp. 44-45.

7. GESAMP (Joint Group of Experts on the Scientific Aspects of Marine Environmental Protection). 1997. Towards safe and effective use of chemicals in coastal aquaculture. Rep. Stu. (IMO/FAO/UNESCO/IOC//WMO/WHO/IAEA/UN/UNEP, 65:40 pp.

8. Giasuddin M. 1993. Coastal fisheries and shrimp farming of Bangladesh. Coastal area resource development and management part II. pp. 114-121.

9. Hossain MM. 1994. A study on fish and shrimp processing industry of Bangladesh. Journalof Aquaculture, 1: 10-15

10. Phillips M. 1996. The use of chemicals in carp and shrimp aquaculture in Bangladesh, Cambodia, Lao PDR, Nepal, Pakistan, Sri Lanka and Viet Nam. In: Use of Chemicals in Aquaculture in Asia. Arthur, J.R., C.R Lavilla-Pitogo, R.P. Subasinghe (eds). Southeast Asian Fisheries Development Center, Aquaculture Department Tigbauan, Iloilo. Philippines. pp 75-84.

11. Pramanik, MAH. 1998. Methodologies and techniques of studying coastal systems-SPARSO case studies CARDMA II: pp. 122-138.

12. Sultana N. 2004 commonly used of chemicals in aquaculture activities in Mymensingh area. 76p. 